\title{
Biochemical Changes Induced By the Effect of Six Pathogenic Fungi on Dialium Guineense: Black Velvet Edible Fruit
}

\author{
Nwaukwu, Ijeoma Adaku ${ }^{1}$ and Ikechi - Nwogu, Chinyerum ${ }^{2}$ \\ ${ }^{I}$ (Department of Plant Science and Technology, Faculty of Natural Sciences, University of Jos, Plateau State - \\ Nigeria) \\ ${ }_{2}^{2}$ (Department of Plant Science and Biotechnology, Faculty of Sciences, University of Port Harcourt, Rivers State- \\ Nigeria)
}

\begin{abstract}
The following fungi (Aspergillus niger, Aspergillus flavus, Botryodiplodia theobromae, Fusarium oxysporum, Penicillium chrysogenum and Rhizopus stolonifer,) were isolated from diseased fruits. Changes in the Proximate content in D. quineense edible fruit inoculated with the test organisms were carried out. The effect of the test organisms on the mineral composition and vitamin content was carried out using the methods recommended by Association of Official Analytical Chemist (AOAC). There was a significant increase $(P<0.05)$ by several degrees caused by the test fungi in moisture, protein and ash, while there was a significant decrease in dry matter, crude lipid, carbohydrate and crude fiber when compared to the uninoculated control. There was significant decrease $(P<0.05)$ in all the mineral compositions $(\mathrm{Ca}, \mathrm{Cu}, \mathrm{Fe}, \mathrm{Mg}, \mathrm{P}, \mathrm{K}$ and $\mathrm{Na})$ caused by the fungi inoculated fruits when compared to the uninoculated fruit control. The vitamin content (Vit. $A, B_{2}, B_{3}$, and $C)$ of the fungi inoculated fruits decreased significantly when compared with the control. The vitamin $C$ content of D. guineense is known to be very high (49.50\%), but was reduced drastically by Botryodiplodia theobromae (20.50\%). The inoculated fungi caused an increase in anti-nutrient (oxalate, phytate, tannin, saponins and trypsin inhibitors) content of the edible pulp.
\end{abstract}

Keywords: Biochemical compositions, D. guineense, Nutrients, Pathogenic fungi

\section{Introduction}

Black Velvet tamarind (Dialium guineense) is a woody plant that occurs in the rain forest region of West Africa. It grows up to $15 \mathrm{~m}$ high with dark green glossy leaves each measuring $6 \mathrm{~cm}$ to $8 \mathrm{~cm}$ long and $2.5 \mathrm{~cm}$ wide at the widest part of the leaf (Okegbile and Taiwo, 1990). The young leaves are sometimes chewed for its tangy taste. A well-established velvet tamarind plant bears one set of fruit per year and yields up to 200kg of fruits annually. The ripe fruits are available from January till May but the peak period for harvest is between March and April, (Orhue et. al., 2007). The velvet tamarind pulp is eaten in Southeastern Nigeria (where it is known as "Icheku" or Nchichi") because of its refreshing properties and pleasant scorching taste. The mature dry circular pods are cracked open (manually) to release the semi-dry edible fruit pulp, which also embeds the seed. Black velvet Tamarind has been found to contain high about of vitamin C (ascorbic acid) and other nutrients (Dike, 2010). These nutrients are being affected by pathogenic fungi in diverse degrees. (IkechiNwogu and Nwaukwu, 2012) identified six pathogenic fungi that are found growing on the edible fruit of Tamarind. These pathogenic fungi are; Aspergillus niger, Aspergillus flavus, Botryodiplodia theobromae, Fusarium oxysporum, Penicillium chrysogenum and Rhizopus stolonifer, which have mycotoxins that lowers the nutritional value of the fruit.

This study is carried out to find out the effect of the above fungi on the biochemical composition (Proximate, Vitamin C, Mineral content and Anti-nutritional factors) of the Dialium guineense fruit.

\section{Materials and Methods}

\subsection{Isolation and identification of fungi.}

The fungi used in this study (Aspergillus niger, Aspergillus flavus, Botryodiplodia theobromae, Fusarium oxysporum, Penicillium chrysogenum and Rhizopus stolonifer,) were isolated from diseased friuts using the standard Blotter method recommended by the international Seed Testing Association (ISTA, 1976 and Agar method (Klement and Voros, 1974). The fungi were identified under a Stereobinocular microscope based on their habit characteristics. Slides were made to confirm identification following descriptions by international Mycological Institude (IMI fungi Descriptions). Pure, single spore cultures of each fungi were obtained by growing them on potato dextrose agar (PDA). The cultures were grown in complete darkness in an incubator for 7 days at $21 \pm 2{ }^{\circ} \mathrm{C}$ they were used as inoculum. 


\subsection{Inoculation of Seeds with Fungi}

One hundred grams of healthy Dialium guineense fruits were weighed out and cleaned by removing the pulp aseptically. The cleaned edible fruit was then put into $25 \mathrm{ml}$ conical flasks, plugged with non -absorbent cotton wool and covered with foil and then autoclaved at $121^{\circ} \mathrm{C}$ for 15 minutes at 15PSI to eliminate any internal and external seed borne micro- organism (Ward and Diener, 1961). After autoclaving the flasks were allowed to cool and $100 \mathrm{ml}$ of sterile distilled water was added to each flask and shaken gently to wet all the seeds and to create a humid and conducive environment for the fungi to be inoculated to have an even distribution. Each flask containing seeds was inoculated with a disc of 7 day old mycelium spores of each fungus obtained from the pure culture of isolated fungi from infected seeds. This was done with a $1.5 \mathrm{~cm}$ diameter sterile cork borer.

The flasks were gently shaken for about 15 minutes to obtain uniform distribution of the mycelium among the seeds. The control flask, received the same treatment, but there was no fungi added to it. The entire flasks which include the fungi inoculated and uninoculated seeds were incubated at room temperature in complete darkness for 14 days.

A total of 18 flasks were used, 3 flasks replicate for each set of fungi inoculated seeds and uninoculated seeds. They were incubated for 14 days in a dark incubated area. At the end of the incubated period, the flasks of each fungal treatment and flasks for control were harvested for biochemical analysis. The seeds in each flask were transferred into a pre-weighed watch glass, dried at $45^{\circ} \mathrm{C}$ for 24 hours and the spores and mycelia of the fungi removed by sieving (Ward and Diener, 1961). Biochemical analysis of various nutrient component (Dry Matter, Moisture, Crude Lipid, Crude Protein, Crude Fiber, Ash content and Carbohydrates in both fungusinoculated and uninoculated seeds at the incubation period of 14 days were determined, also the effect of the fungi on the Vitamin $\mathrm{C}$ content and the anti-nutrient content of the fruit was carried out following procedures recommended by the Association of Official Analytical Chemists (AOAC, 1995). The results of each component were subjected to statistical analysis using the Analysis of Variance (ANOVA).

\section{Results and Discussions}

The effects of the fungi on the biochemical component of the fruits were carried. The moisture content of the fungi - inoculated seeds increased $(\mathrm{p}=0.05)$ when compared with the uninoculated control (6.6). This is presented in (Table 1). Botryodiplodia theobromae (15.5) caused the highest increase in moisture followed by Rhizopus stolonifer (12.24) The increase caused by the fungi is due to their utilization of the component of the seeds as food nutrient thereby producing water in the process. Similar results were recorded by Ataga and Akueshi (1986) in sunflower seeds inoculated with fungi. Ataga and Umechuruba (1997) also reported increase in moisture content of African Yam Bean inoculated with storage fungi. The reverse is the case for Dry Matter. There was a significant decrease $(\mathrm{P}=0.05)$ from the control seeds when compared to inoculated seeds with Fungi. This fungus produces extracellular cellulolytic and pectic enzyme and secondary metabolites which may be responsible for the drastic depletion of dry matter (Okonkwo et al., 1990).

There was also a decrease in carbohydrate of fungi inoculated seeds as when compared with the uninoculated control. The decrease in the inoculated seeds could be due to the utilization of storage starch and sugar as a carbon source by the microorganisms during respiration and also a source of energy for microbial growth (Monday, 2005).

The protein content of the fungi inoculated seeds, increased significantly when compared to the uninocualted control. The increase caused could be due to the presence of proteinaceous mycelium in the fungi. Cherry and Beuchat, (1975) obtained a similar result in their study of protein changes in groundnut seeds infected with Neurospora sitophila and Rhizopus oligosporu which he said resulted from slight protein synthesis by the proliferation of the fungal hyphae and the synthesis of enzyme protein or other constituents.

There was a significant decrease of lipid of the uninoculated control when compared to the fungi inoculated seeds. This agrees with the findings of Ogundero, (1992) who explained that the decrease in oil content could be due to the hydrolysis of oil to free fatty acid (FFA). This occurred at different rates for the individual fungi pathogens.

There was a drastic and significant decrease in fiber of all the seeds inoculated with the individual fungi when compared to the control. This experiment agrees with the report of (Onifade et al, 2004), about a decrease in crude fiber content of sweet potato flour enriched with A. niger. He also explained that the crude fiber tends to decrease during fermentation. This he concluded was a result of being utilized by the fermentation microbes.

There was significant increase in ash of the individual fungi when compared to the uninoculated control. For the fungi, Ataga and Umechuruba (1997) resolved that the increase could be attributed to the presence of minerals like potassium and phosphorous in the mycelia of the fungi.

The mineral content of the D. guineense fruit infected by the different test fungi showed that there was a significant decrease in the mineral composition of the seeds when compared to the uninoculated control. This 
Biochemical Changes Induced By The Effect Of Six Pathogenic Fungi On Dialium Guineense: Black is a shown in (Table 2). This shows that when infected fruits are eaten, they lack adequate basic mineral nutrients.

Black velvet Timarid has a high content of Vitamin C and Vitamin A as shown in ( Table 3). However, the text fungi caused significant decrease in the vitamin content of the edible fruit.

The text organisms caused a significant increase in the antioxidant content of the edible fruit. This could have resulted as a result of the introduction of mycotoxins by the fungi. This causes food poison. This is shown in (Table 4).

TABLE 1: Changes in the Proximate Content in D. quineense Edible Fruit inoculated with Aspergillus niger, Aspergillus flavus, Botryodiplodia theobromae, Fusarium oxysporum, Penicillium chrysogenum and Rhizopus stolonifer

\begin{tabular}{|c|c|c|c|c|c|c|c|}
\hline \multirow[t]{2}{*}{ Test Fungi } & \multicolumn{7}{|c|}{ Proximate Composition (\%W/W)/100g } \\
\hline & $\begin{array}{l}\text { Dry } \\
\text { Matter }\end{array}$ & Moisture & $\begin{array}{l}\text { Crude } \\
\text { Lipid }\end{array}$ & $\begin{array}{ll}\text { Crude } & \mathrm{Ca} \\
\text { Protien } & \end{array}$ & Carbohydrate & $\begin{array}{l}\text { Crude } \\
\text { Fibre }\end{array}$ & Ash \\
\hline \multicolumn{8}{|c|}{ (Uninoculated) } \\
\hline Control & $93.3 \pm 1.48 \mathrm{a}$ & $6.6 \pm 0.10 \mathrm{c}$ & $4.25 \pm 0.03 \mathrm{a}$ & $5.71 \pm 0.10 \mathrm{~b}$ & $84.1 \pm 1.32 \mathrm{a}$ & $0.5 \pm 0.01 \mathrm{a}$ & $3.01 \pm 0.01 \mathrm{~d}$ \\
\hline $\begin{array}{l}\text { Aspergillus } \\
\text { niger }\end{array}$ & $89.65+1.43 b$ & $10.35 \pm 0.12 \mathrm{c}$ & $3.19 \pm 0.23 \mathrm{a}$ & $6.34 \pm 0.31 \mathrm{a}$ & $75.53 \pm 0.07 \mathrm{~b}$ & $0.23 \pm 0.03 \mathrm{c}$ & c $4.59 \pm 0.09 \mathrm{c}$ \\
\hline $\begin{array}{l}\text { Aspergillus } \\
\text { flavus }\end{array}$ & $91.28 \pm 1.02 \mathrm{a}$ & $8.72 \pm 1.47 \mathrm{c}$ & $2.10 \pm 0.55 \mathrm{~b}$ & $6.27 \pm 0.01 \mathrm{a}$ & $73.32 \pm 0.02 \mathrm{c}$ & $0.4 \pm 0.03 b$ & $3.98 \pm 0.06 \mathrm{~d}$ \\
\hline $\begin{array}{l}\text { Botryodiploc } \\
\text { theobromae }\end{array}$ & $84.5 \pm 1.67 \mathrm{c}$ & c $15.5 \pm 1.02 \mathrm{a}$ & $1.25 \pm 0.02 \mathrm{c}$ & $6.89 \pm 0.16 \mathrm{a}$ & $60.2 \pm 1.75 \mathrm{e}$ & $0.3 \pm 0.01 \mathrm{c}$ & $6.50 \pm 0.02 \mathrm{a}$ \\
\hline $\begin{array}{l}\text { Fusarium } \\
\text { oxysporum }\end{array}$ & $86.25 \pm 0.15 \mathrm{c}$ & $9.75 \pm 0.23 \mathrm{c}$ & $2.95 \pm 0.12 \mathrm{~b}$ & $6.02 \pm 0.01 b$ & $68.5 \pm 0.14 \mathrm{~d}$ & $0.15 \pm 0.01 \mathrm{c}$ & lc $5.02 \pm 0.03 b$ \\
\hline $\begin{array}{l}\text { Penicillium } \\
\text { chrysogenum }\end{array}$ & $n 92.08 \pm 0.11 \mathrm{a}$ & $7.92 \pm 0.01 \mathrm{c}$ & $2.56 \pm 0.03 b$ & $6.56 \pm 0.01 \mathrm{a}$ & $70.26 \pm 0.01 \mathrm{~d}$ & $0.2 \pm 0.04 \mathrm{c}$ & $5.29 \pm 0.01 \mathrm{~b}$ \\
\hline $\begin{array}{l}\text { Rhizopus } \\
\text { Stolonifer }\end{array}$ & $85.0 \pm 0.15 \mathrm{c}$ & $12.24 \pm 1.21 \mathrm{~b}$ & $3.90 \pm 0.02 \mathrm{a}$ & $6.75 \pm 1.21 \mathrm{a}$ & $69.4 \pm 1.25 \mathrm{~d}$ & $0.25 \pm 0.04 \mathrm{c}$ & c $4.62 \pm 0.06 \mathrm{c}$ \\
\hline L.S.D $(0.05)$ & 1.54 & 0.4 & 0.8 & 0.6 & 1.27 & 0.1 & 0.3 \\
\hline
\end{tabular}

Mean of two determinations with three replications \pm Standard Error. L.S.D- Least Significant Difference Values with the same alphabet along column are not significantly different at $(\mathrm{P}<0.05)$

TABLE 2: Changes in the Mineral Content in D. quineense Edible Fruit inoculated with Aspergillus niger, Aspergillus flavus, Botryodiplodia theobromae, Fusarium oxysporum, Penicillium chrysogenum and Rhizopus stolonifer

\begin{tabular}{|c|c|c|c|c|c|c|c|}
\hline \multirow[t]{2}{*}{ Test Fungi } & \multicolumn{7}{|c|}{ Mineral Composition (\%W/W)mg/100g } \\
\hline & $\begin{array}{l}\text { Calcium } \\
\text { (Ca) }\end{array}$ & $\begin{array}{c}\text { Copper } \\
(\mathrm{Cu})\end{array}$ & $\begin{array}{l}\text { Iron } \\
\qquad(\mathrm{Fe})\end{array}$ & $\begin{array}{l}\text { Magnesium } \mathrm{Ph} \\
(\mathrm{Mg})\end{array}$ & $\begin{array}{l}\text { hosphorus Po } \\
\text { (P) }\end{array}$ & $\begin{array}{l}\text { otassium } \\
(\mathrm{K})\end{array}$ & $\begin{array}{l}\text { gdium } \\
\text { (Na) }\end{array}$ \\
\hline \multicolumn{8}{|c|}{ (Uninoculated) } \\
\hline Control & $47.0 \pm 0.40 \mathrm{a}$ & $1.0 \pm 0.04 \mathrm{a}$ & $4.1 \pm 0.40 \mathrm{a}$ & $300 \pm 14.12 \mathrm{a}$ & $42.9 \pm 0.40 \mathrm{a}$ & $260 \pm 14.14 \mathrm{a}$ & $390 \pm 15.42 \mathrm{a}$ \\
\hline $\begin{array}{l}\text { Aspergillus } \\
\text { niger }\end{array}$ & $45.5 \pm 1.02 \mathrm{a}$ & $0.9 \pm 0.01 \mathrm{a}$ & $3.9 \pm 0.12 b$ & $250 \pm 10.19 d$ & $40 \pm 0.05 b$ & $190 \pm 10.50 \mathrm{e}$ & $250 \pm 16.12 d$ \\
\hline $\begin{array}{l}\text { Aspergillus } \\
\text { flavus }\end{array}$ & $46.4 \pm 0.12 \mathrm{a}$ & $0.7 \pm 0.38 \mathrm{a}$ & $3.7 \pm 0.35 \mathrm{c}$ & $235 \pm 10.25 \mathrm{e}$ & $39.25+1.23 \mathrm{c}$ & $230 \pm 11.70 \mathrm{~b}$ & $200 \pm 11.12 \mathrm{f}$ \\
\hline \multicolumn{8}{|c|}{ Botryodiplodia } \\
\hline $\begin{array}{l}\text { Fusarium } \\
\text { oxysporum }\end{array}$ & $30.2 \pm 0.12 \mathrm{e}$ & $0.35 \pm 0.01 b$ & $\begin{array}{r}3.25 \pm 0.42 \mathrm{c} \\
\text { www.iosr }\end{array}$ & $\begin{array}{l}\mathrm{d} \quad 150 \pm 15.2 \mathrm{~g} \\
\text { rjournals.org }\end{array}$ & $32.2 \pm 2.25 \mathrm{~d}$ & $105 \pm 13.2 \mathrm{f}$ & $\begin{array}{r}150+13.2 \mathrm{~g} \\
22 \mid \text { Page }\end{array}$ \\
\hline
\end{tabular}


Biochemical Changes Induced By The Effect Of Six Pathogenic Fungi On Dialium Guineense: Black

Penicillium

chrysogenum $43.0 \pm 21.24 \mathrm{~b} \quad 0.80 \pm 0.01 \mathrm{a} \quad 3.4 \pm 0.12 \mathrm{c} \quad 200 \pm 10.2 \mathrm{f} \quad 37.5 \pm 2.35 \mathrm{c} \quad 200 \pm 2.50 \mathrm{~d} \quad 300 \pm 12.5 \mathrm{c}$

Rhizopus

Stolonifer $\quad 39.5 \pm 1.21 \mathrm{c} \quad 0.5+0.72 \mathrm{a} \quad 3.50 \pm 0.28 \mathrm{a} \quad 280 \pm 7.25 \mathrm{~b} \quad 36.3 \pm 1.27 \mathrm{c} \quad 190 \pm 11.5 \mathrm{e} \quad 350 \pm 15.3 \mathrm{~b}$

$\begin{array}{lllllll}\text { L.S.D }(0.05) & 0.9 & 0.1 & 0.1 & 1.53 & 1.50 & 1.54\end{array}$

Mean of two determinations with three replications \pm Standard Error. L.S.D- Least Significant Difference

Values with the same alphabet along column are not significantly different at $(\mathrm{P}<0.05)$

TABLE 3: Changes in Vitamin Content in D. quineense Edible Fruit inoculated with Aspergillus niger, Aspergillus flavus, Botryodiplodia theobromae, Fusarium oxysporum, Penicillium chrysogenum and Rhizopus stolonifer

\begin{tabular}{|c|c|c|c|c|c|c|c|c|}
\hline \multicolumn{3}{|c|}{$\begin{array}{l}\text { Vitamin Composition } \\
(\% \mathrm{~W} / \mathrm{W}) \mathrm{mg} / \mathbf{1 0 0 g}\end{array}$} & \multicolumn{6}{|c|}{ Test Fungi } \\
\hline \multirow{2}{*}{\multicolumn{2}{|c|}{ Control }} & Aspergillus & Aspergillus & Botryodiplodia & Fusarium $I$ & Penicillium $R h$ & zopus & \\
\hline & & niger & flavus & theobromae & oxysporum & n chrysogenum & stolonife & - LSD \\
\hline Vitamin A & $3.00 \mathrm{a}$ & $1.70 \mathrm{~b}$ & $1.90 \mathrm{~b}$ & $1.50 \mathrm{~b}$ & $1.05 b$ & $2.5 b$ & $2.90 \mathrm{a}$ & 0.5 \\
\hline Vitamin B2 & $0.07 \mathrm{a}$ & $0.05 \mathrm{a}$ & $0.05 \mathrm{a}$ & $0.025 b$ & $0.06 \mathrm{a}$ & $0.055 \mathrm{a}$ & $0.04 b$ & 0.02 \\
\hline Vitamin B3 & $0.52 \mathrm{a}$ & $0.35 \mathrm{c}$ & $0.45 b$ & $0.20 \mathrm{e}$ & $0.25 \mathrm{~d}$ & $0.37 \mathrm{c}$ & $0.36 \mathrm{c}$ & 0.03 \\
\hline$\underline{\text { Vitamin } \mathrm{C}}$ & $49.50 \mathrm{a}$ & $40.5 \mathrm{~b}$ & $39.5 b$ & $20.50 \mathrm{e}$ & $35.5 \mathrm{~d}$ & $37.5 \mathrm{c}$ & $36.5 \mathrm{c}$ & 1.56 \\
\hline
\end{tabular}

Mean of two determinations with three replications. L.S.D- Least Significant Difference

Values with the same alphabet along row are not significantly different at $(\mathrm{P}<0.05)$

TABLE 4: Changes in Anti-nutrient Content in D. quineense Edible Fruit inoculated with Aspergillus niger, Aspergillus flavus, Botryodiplodia theobromae, Fusarium oxysporum, Penicillium chrysogenum and Rhizopus stolonifer

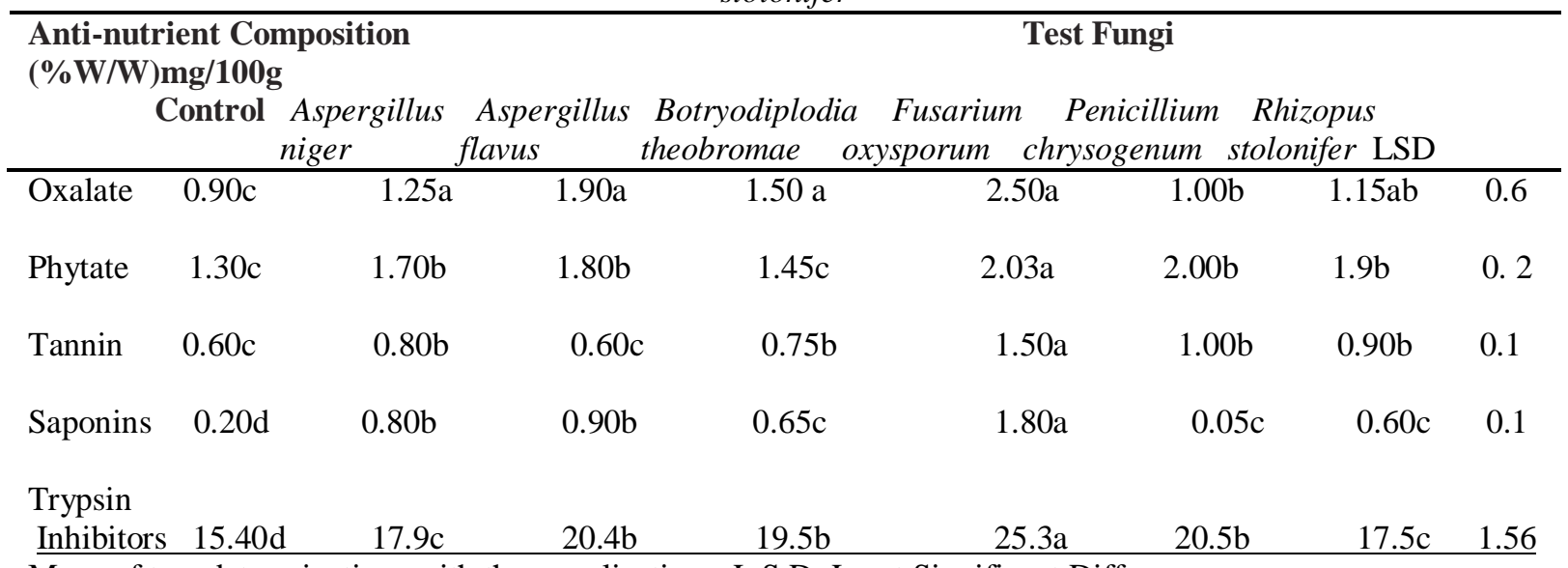

Mean of two determinations with three replications. L.S.D- Least Significant Difference

Values with the same alphabet along row are not significantly different at $(\mathrm{P}<0.05)$

\section{Conclusion}

The research emphasized the role pathogenic fungi affect the nutritional composition of the edible fruit of $D$. guineenses, a fruit mostly eaten in Africa. It is advised that infected fruits should not be eaten because it causes food poison. 


\section{References}

[1] AOAC (1995). Official Methods of Analysis (16 ${ }^{\text {th }}$ edition) Association of Official Analytical Chemists. Virginia, USA. 1018p.

[2] Ataga, A. E. and Akueshi, C.O. (1986). Fungi associated with sunflower seeds in Nigeria. Seed Research 1(24): 64 -65.

[3] Ataga, A.E. \& Umechuruba, C.I. (1997). Biochemical changes in Africam Yam bean seeds caused by Botryodiplodia theobromae, Fusarium palidoreseum and Penicillium cxaliam. Global Journal of Pure and Applied Science 4(4): 381-384.

[4] Cherry, J. O. P. And Beuchat, L.R. (1975). Comparative studies of protein and amino acid changes in peanuts, infected with Neurospora sitophila and Rhixzopus oligosporus. Cereal Chemistry 53:750-761

[5] Dike, M. C. (2010) Proximate, phytochemical and nutrient compositions of some Fruits, Seeds and leaves of some Plant Species at Umudike, Nigeria. ARPN Journal of Agricultural and Biological Science. Vol. 5, no1, pp 7-16.

[6] Ikechi-Nwogu, C. and Nwaukwu, I. A. (2012). Fungi Pathogens Associated with Forest Friut Dialium quineense (Icheku) in Port Harcourt Metropolis. Scientia Africana, Vol.11 (No. 1), June 2012. Pp 107-113.

[7] ISTA (1976). International Seed Testing Association. International Rules for Seed Testing. Seed Science and Technology 4: 51-77.

[8] Klement, Z. K. and Voros, I. C., (1974) Methods in Pathology. Elsevier Scientific Publishing Co., Amsterdam, London. Pp. 220288.

[9] Monday, N.A.G. and Ataga A.E. (2005). The Role of Aspergillus niger, Aspergillus flavus, and Fusarium oxysporum on the nutritional composition and contents of cyperus esculentus L. (B.Sc Thesis)

[10] Ogundero, V. W. (1992). Hydrolysis of vegetable oils and triglycerides by thermotolerant and zoopathogenic species of Aspergillus from Nigeria Palm Produce. Mycopathogia, 77: 43-46.

[11] Okegbile E.O. and Taiwo E.A. (1990): Nutritional Potentials of Velvet Tamarind (Dialium guineense Wild). Nig Food Journal 8: $115-121$

[12] Okonkwo, S.N., Amund, O.O and Ogunsanya, C.O. (1990). Microbial rotting and preservation of banana fruit (Musa sapientium L) in Nigeria. Microbes. Letters 44:175-176

[13] Oladejo, Thomas (2009). Proximate composition and micronutrient potentials of three locally available wild fruits in Nigeria. African Journal of Agricultural Research Vol. 4 (9), pp. 887-892.

[14] Onifade, A. K., Atum, H. N. And Adebolu, T. T. (2004). Nutrient enrichment of Sweet potato (Ipomoea batatas L.). Global Journal of Pure and Applied Sciences 10(1):31-36

[15] Orhue, E. R., O., Agbensola, U. and Nosakhare, O. (2007) Growth of Dilium quineense Wild Seedlings and Changes in some Chemical Properties in soil Amended with Brewerly Effluents. Journal of Agronomy 6(4): 548-553.

[16] Ward, H. S. and Diener, U. K. (1961). Biochemical changes in shelled Peanuts caused by fungi. Effects of Aspergillus tamari, four species of A. glaucus group and Penicillium citrinum. Phytopathology. 51: 244-250 